\title{
The Use of Code-Mixing by English Education Department Students during Classroom Activity
}

\author{
Faezal Tanjung1, Furqanul Hakim² \\ ${ }^{1,2}$ STKIP Paracendekia NW Sumbawa, Sumbawa, Nusa Tenggara Barat \\ E-mail: faezaltanjung5@gmail.com, furqanulstkippnws87@gmail.com
}

\begin{tabular}{|c|c|}
\hline Article Info & Abstract \\
\hline Article History & The research aims to find out the types of code-mixing used by English Education \\
\hline Received: $2021-11-10$ & Department students during their presentation activity in the classroom in STKIP \\
\hline $\begin{array}{l}\text { Revised: } 2021-11-28 \\
\text { Published: } 2021-12-06\end{array}$ & Paracendekia NW Sumbawa and to identify why did the students use the code-mixing. \\
\hline & The participants of this research were 4 English Department students of STKIP \\
\hline ds: & $\begin{array}{l}\text { Paracendekia NW Sumbawa. This research used observation, audio recording, and } \\
\text { interview techniques in collecting the data. The result showed that there were two }\end{array}$ \\
\hline Code Mixing; & types of code mixing that used by the students in the presentation process, namely \\
\hline $\begin{array}{l}\text { Classroom Activity; } \\
\text { Presentation Process. }\end{array}$ & insertion code-mixing, and alternation code-mixing. Insertion code-mixing was the \\
\hline & $\begin{array}{l}\text { dominant type that used by the students in the presentation process. There were } 32 \\
\text { utterances categorized as insertion code-mixing, and } 9 \text { utterances were categorized as } \\
\text { alternation code-mixing. While the reasons of the students using code-mixing in the } \\
\text { presentation process were mostly because of the situation and lack of vocabulary. }\end{array}$ \\
\hline
\end{tabular}

\begin{tabular}{l}
\hline Artikel Info \\
\hline Sejarah Artikel \\
Diterima: 2021-11-10 \\
Direvisi: 2021-11-28 \\
Dipublikasi: $2021-12-06$
\end{tabular}

Kata kunci:

Code Mixing;

Aktivitas Classroom;

Presentation Process.

\begin{abstract}
Abstrak
Penelitian ini bertujuan untuk mengetahui jenis-jenis code-mixing yang digunakan oleh mahasiswa Jurusan Pendidikan Bahasa Inggris saat melakukan presentasi di kelas di STKIP Paracendekia NW Sumbawa, selain itu penelitian ini untuk mengidentifikasi mengapa mahasiswa menggunakan code-mixing tersebut. Partisipan dari penelitian ini adalah 4 mahasiswa Jurusan Bahasa Inggris STKIP Paracendekia NW Sumbawa. Penelitian ini menggunakan teknik observasi, rekaman audio, dan wawancara dalam pengumpulan datanya. Hasil penelitian menunjukkan bahwa ada dua jenis code-mixing yang digunakan oleh mahasiswa bahasa Inggris dalam proses presentasi, yaitu codemixing penyisipan, dan code-mixing bergantian. code-mixing penyisipan adalah jenis yang dominan digunakan oleh siswa bahasa Inggris dalam proses presentasi. Terdapat 32 ujaran yang dikategorikan sebagai code-mixing penyisipan, dan 9 tuturan yang dikategorikan code-mixing kode pergantian. Sedangkan alasan siswa menggunakan code-mixing dalam proses presentasi sebagian besar karena situasi dan kurangnya kosakata.
\end{abstract}

\section{INTRODUCTION}

Using English language in classroom interaction is very important for English Foreign Language (EFL) students. For EFL students, classroom is an educational institution where they can practice the language. According to Berliner \& Biddle (1995, in Hai and Bee, 2006, p.116), Students' opportunity to participate actively in the classroom communication contributes to one of the most important predictors of student achievement. In fact, practicing English as a foreign language usually occurs inside the classroom. When they are outside the classroom, they are rare to practice the language since they do not have partners to practice their English.

Recently, using more than one language becomes a life style in modern society. According to Wardaugh (2006, p.101), bilingualism or multilingualism is a literal phenomenon of people who have more than one code (language) in their communication. So, bilingualism is the ability of people who can use two different languages to speak (Hamsia, 2015:36). For those who use more than one language to communicate with others are called bilingualism or multilingualism. (Marlina, 2016, p. 182).

Further more, for those who tend to mix more than one language in their sentences are called code-mixing speakers. It is also stated by Abdullah in Khairunnisa (2016, p. 1), that using two or more languages at the moment of communication in the same sentence is called code-mixing. There are many factors that make students frequently use code mixing when they do presentation in the classroom, such as when the students forget English vocabularies, then they put their native language words into the 
English sentences. Sometimes the students also used code mixing due to the topic that is difficult.

Due to the cotext the researchers wanted to know more about code-mixing phenomenon in the classroom during the presentation process. In fact, at the moment the English Education Department Students of STKIP Paracendekia NW Sumbawa conduct a presentation in the classroom, they usually use two languages, such as Indonesian-English in one sentence. This phenomenon made the researchers tried to study code-mixing used by the students.

Code-mixing is an element of language when the people combine two or more different languages words and phrases into other languages during their communication without changing the topic. According to Ho (2007, p. 2), the compensation of one language to another language within the same utterance or in written text is called code-mixing, Hoffman in Ivana (2018, p. 16) states that there are three types of code mixing. Those are Intra-sentential codemixing, Intra-lexical code-mixing and Involving change of pronunciation.

1) Intra-Sentential Code-Mixing, this type of code mixing happens within a phrase, a clause, or a sentence boundary, the example of intrasentential code-mixing in Indonesian-English is "saya tidak tahu why she did not datang hari ini. "(I don't know why she did not come today)". Based on the example above, it is called intra-sentential code-mixing because the speaker mixed the language between Indonesian and English. The speaker mixed "why she did not" in his/her utterance in Indonesian.

2) Intra-Lexical Code-Mixing, this type of codemixing occurs within a word boundary. The example of intra-lexical code-mixing in Indonesia-English "kamu belum nge-follow Instagram saya (you do not follow my Instagram)". the speaker mixed English and Indonesian at the level of word and it is called intra-lexical code-mixing.

3) Involving a Change of Pronunciation, this type of code mixing occurs at the phonological level. At the moment Indonesian people speak in English word, but modified to Indonesian phonological structure. For example, the word of "hello" is said "halo" or the word "strawberry is said to be "stroberi" by Indonesian people, the word telephone" is said "telepon" This phenomenon occurs in Indonesia because many people in Indonesia often use those words in their daily interaction.

Muysken in Sukrisna (2019, p. 28) explains another three types of code-mixing such as:

1) Insertion is the type of code-mixing when the speaker inserts a word from other language to another different language during communication orally and written. Usually, many people use Insertion because they do not know the meaning of the word in their native language, so that they tend to continue their talk by mixing it with another language. For example, "tolong jangan bully saya".

2) Alternation occurs between clauses. Meaning that alternation is used when a speaker mixes his or her language with a phrase. In this type, the speaker mixes their native language with foreign language. They insert the phrase of foreign language in their native language. For example: "Saya tidak bisa bantu karena masih a little bit busy".

3) Congruent Lexicalization is the influence of dialect within the language use. It means that when the speaker communicates using Indonesia language and the words which come out from his or her mouth it is like a foreign language. For example "kenapa kamu lama sekali mengangkat telephone saya".

According to Nababan in Ivana (2018, p. 18), some factors that lead people to do code-mixing are:

Firstly, Bilingualism. This factor talks about the ability of a people to use two languages. Secondly, Situation can be also a reason by someone uses code-mixing. For example it can be happened in a relax situation, and in formal or informal situations. The third is Prestige, English is spoken in many other countries in the world and used as language of international communication. People must master both oral and written (Handayani, 2016, p. 102). The implication is seen through the phenomenon of using code-mixing among modern society. The forth is Vocabulary can be also a factor of people using code-mixing. People talk with other people and use foreign language, but in one situation the speaker do not know the meaning of the word that will be used. It means that when there is a lack of vocabulary in one language, the speakers forget or difficult to find out the meaning of the word. That is why many people change the word 
into another language. According to Muflihah (2016, p. 94), Code-mixing occurs when someone mixes the language in the form of word, phrases, or sentence into another language.

\section{METHOD}

This study applied descriptive qualitative method by using naturalistic design. It is used in order to discover, analyze, identify, and also describe the code-mixing used by students in the classroom activity especially in the presentation process. This research was conducted in STKIP Paracendekia NW Sumbawa. In conducting the research, the researchers used purposive sampling technique. The researchers took four English Department Students in sixth semester to be the respondents of this research, to get the data, the researchers conducted some ways to collect the data. Those are observation, audio and video recording and interview. Meanwhile, the researchers also need supporting instruments such as audio recorder, and camera (cellphone), pens, notebook, and questionaires. To collect the data, cellphone was used to record and take the pictures of the activities or presentation process of the students in the classroom, pens and note book were used to write field notes. Based on the supporting instruments above, the researchers used it to ease the process of collecting and obtaining the data about code-mixing used by English Department Students of STKIP Paracendekia NW Sumbawa in academic year $2020 / 2021$. To analyse the data, the researchers used data reduction, data display, and Drawing Conclusion / Verification techniques.

\section{FINDINGS AND DISCUSSION}

The observation sessions were conducted from 22 February to 16 March 2021. The result of observation was used to find out the types of code-mixing that used by the students. While, the interview sessions were conducted from 17-20 March 2021. In the interview sessions, the writers interviewed the students to know the reasons of using Code-Mixing in their presentation process. In classifying the types of code-mixing, the researchers used Muysken's theory which divides it into three types, they are: insertion code-mixing, alternation code-mixing, and congruent lexicalization. In this case, the researchers analyzed the types of code mixing that used by the students. Here are the utterances the researchers found after doing the observation from $15^{\text {th }}$ February to $8^{\text {th }}$ March 2021:
Table 1. Types of Code Mixing Used by Respondent 1. (WDM)

\begin{tabular}{|c|c|c|c|c|}
\hline \multirow{2}{*}{ NO } & \multirow{2}{*}{ Utterances } & \multicolumn{3}{|c|}{ Types of code Mixing } \\
\hline & & ICM & ACM & CLCM \\
\hline 1. & $\begin{array}{l}\text { The point of curriculum, Terry } \\
\text { Regret berkata bahwa } \\
\text { curriculum change under } \\
\text { successive governments. }\end{array}$ & $\sqrt{ }$ & & \\
\hline 2. & $\begin{array}{l}\text { So kalau kita indonesiakan } \\
\text { seorang doctor yang bernama } \\
\text { Terry Regret mengatakan } \\
\text { bahwa kurikulum itu berubah- } \\
\text { ubah di bawah } \\
\text { pemerintahannya yang } \\
\text { berurut-urut, }\end{array}$ & $\sqrt{ }$ & & \\
\hline 3. & $\begin{array}{l}\text { Jadi di garis bawahi kata } \\
\text { politisme ini erat banget } \\
\text { dengan pemerintahan }\end{array}$ & $\sqrt{ }$ & & \\
\hline 4. & $\begin{array}{l}\text { For example di Indonesia } \\
\text { sendiri pada era presiden } \\
\text { sebelumnya dengan era } \\
\text { president jaman sekarang itu } \\
\text { menteri pendidikannya } \\
\text { berbeda }\end{array}$ & $\sqrt{ }$ & & \\
\hline 5. & $\begin{array}{l}\text { because of that praturan yang } \\
\text { di berikan atau kurikulum yang } \\
\text { di berikan oleh menteri } \\
\text { Pendidikan }\end{array}$ & $\sqrt{ }$ & & \\
\hline 6. & $\begin{array}{l}\text { Ministry government now it's } \\
\text { different with another menteri } \\
\text { pendidikan pada era } \\
\text { sebelumnya. }\end{array}$ & & $\sqrt{ }$ & \\
\hline 7. & $\begin{array}{l}\text { jadi masing-masing ministry } \\
\text { government itu di setiap eranya } \\
\text { tentu berbeda }\end{array}$ & $\sqrt{ }$ & & \\
\hline 8. & $\begin{array}{l}\text { sebuah kurrikulum tentu } \\
\text { memiliki planning }\end{array}$ & $\sqrt{ }$ & & \\
\hline 9. & $\begin{array}{l}\text { bagaimana caranya how to } \\
\text { achieve program and how to } \\
\text { take the error dan terdapat } \\
\text { delapan nilai program. }\end{array}$ & & $\sqrt{ }$ & \\
\hline 10. & $\begin{array}{l}\text { menetukan goals dari program } \\
\text { tersebut, mendesain program, } \\
\text { establish the program } \\
\text { assessment procedures, }\end{array}$ & $\sqrt{ }$ & & \\
\hline 11. & $\begin{array}{l}\text { Next, Jadi curriculum studies } \\
\text { has emerged from an attempt } \\
\text { to study education and to } \\
\text { explore educational problems } \\
\text { in their own right and not as } \\
\text { philosophical problems or as } \\
\text { psychological or sociological } \\
\text { phenomena. }\end{array}$ & $\sqrt{ }$ & & \\
\hline 12. & $\begin{array}{l}\text { kita mengikuti sebuah aturan } \\
\text { dari Negara itu sendiri and ini } \\
\text { bukan sebuah problem } \\
\text { psikologi. }\end{array}$ & $\sqrt{ }$ & & \\
\hline
\end{tabular}

Table 2. Types of Code Mixing used by Respondent 2. (SPI)

\begin{tabular}{llll}
\hline & & \multicolumn{2}{c}{ Types of code } \\
No & Student Utterances & \multicolumn{2}{c}{ Mixing } \\
\cline { 3 - 4 } & ICM & ACM $\quad$ CLCM \\
\hline 1. & $\begin{array}{l}\text { but sebelum kita menuju ke } \\
\text { pembahasan yang lebih jauh }\end{array}$ & $\sqrt{ }$ \\
\hline $\begin{array}{l}\text { materi saya kali ini first saya } \\
\text { akan mencoba untuk explain } \\
\text { kepada teman-teman }\end{array}$ & $\sqrt{ }$ \\
\hline $\begin{array}{l}\text { Ok next yang akan saya jelaskan } \\
\text { di poin yang kedua }\end{array}$ & $\sqrt{ }$ \\
\hline
\end{tabular}




\begin{tabular}{|c|c|c|c|}
\hline 4. & $\begin{array}{l}\text { poin yang kedua adalah the } \\
\text { centrality of the teacher }\end{array}$ & & $\sqrt{ }$ \\
\hline 5. & $\begin{array}{l}\text { in here terdapat some points } \\
\text { juga yaitu }\end{array}$ & $\sqrt{ }$ & \\
\hline 6. & $\begin{array}{l}\text { dan yang terakhir adalah } \\
\text { conclusion. }\end{array}$ & $\sqrt{ }$ & \\
\hline 7. & $\begin{array}{l}\text { poin yang pertama yakni what is } \\
\text { the curriculum }\end{array}$ & & $\sqrt{ }$ \\
\hline 8. & $\begin{array}{l}\text { the educational curriculum is } \\
\text { number or subject atau we can } \\
\text { say kurikulum adalah sejumlah } \\
\text { mata pelajaran }\end{array}$ & $\sqrt{ }$ & \\
\hline 9. & $\begin{array}{l}\text { And the last, kurrikulum adalah } \\
\text { segala sesuatu yang di proleh } \\
\text { siswa di bawah tanggungjawab } \\
\text { sekolah. }\end{array}$ & $\sqrt{ }$ & \\
\hline 10. & $\begin{array}{l}\text { Dari bebrapa pengertian para ahli } \\
\text { tadi we can make the } \\
\text { conclusion }\end{array}$ & & $\sqrt{ }$ \\
\hline 11. & $\begin{array}{l}\text { dan untuk memastikan itu adalah } \\
\text { sebuah curriculum or not kita } \\
\text { merujuk kepada pengertian of } \\
\text { sujiarto }\end{array}$ & $\sqrt{ }$ & \\
\hline 12. & $\begin{array}{l}\text { Next to the total of curriculum } \\
\text { yaitu Sekolah harus } \\
\text { merencanakan kurikulum }\end{array}$ & & $\sqrt{ }$ \\
\hline 13. & $\begin{array}{l}\text { kurrikulum yang di tawarkan by } \\
\text { sekolah dan kurikulum yang di } \\
\text { terima by setiap siswa tidak } \\
\text { boleh hanya menjadi kumpulan } \\
\text { mata pelajaran yang terpisah }\end{array}$ & $\sqrt{ }$ & \\
\hline 14. & $\begin{array}{l}\text { The hidden curriculum meliputi } \\
\text { yang tidak di pelajari dari } \\
\text { program skolah }\end{array}$ & & $\sqrt{ }$ \\
\hline 15. & $\begin{array}{l}\text { the other meaning bahwa } \\
\text { hidden kuriculum adalah suatu } \\
\text { hal yang berhubungan dengan } \\
\text { kurrikulum pendidikan moral dan } \\
\text { peran guru dalam } \\
\text { menstransformasikan standar } \\
\text { moral }\end{array}$ & $\sqrt{ }$ & \\
\hline 16. & $\begin{array}{l}\text { berpengaruh baik secar langsung } \\
\text { maupun secara tidak langsung } \\
\text { terhadap output dari proses } \\
\text { belajar mengajar }\end{array}$ & $\sqrt{ }$ & \\
\hline 17. & $\begin{array}{l}\text { yang di maksut dengan plan of } \\
\text { curriculum adalah semua yang } \\
\text { tertuang dalam syllabus dan } \\
\text { sebagainya }\end{array}$ & & $\sqrt{ }$ \\
\hline
\end{tabular}

Table 3. Types of Code Mixing used by Respondent 3. (ASM)

\begin{tabular}{|c|c|c|c|c|}
\hline \multirow[t]{2}{*}{ No } & \multirow[t]{2}{*}{ Student Utterances } & \multicolumn{3}{|c|}{$\begin{array}{c}\text { Types of code } \\
\text { Mixing }\end{array}$} \\
\hline & & ICM & ACM & CLCM \\
\hline 1. & $\begin{array}{l}\text { Dan sekrang kita Next to } \\
\text { several opportunities }\end{array}$ & & $\sqrt{ }$ & \\
\hline 2. & $\begin{array}{l}\text { terdapat beberapa analisis } \\
\text { peluang by Ralph Tyler dari } \\
\text { elemen kunci perencanaan } \\
\text { kuriklum }\end{array}$ & $\sqrt{ }$ & & \\
\hline 3. & $\begin{array}{l}\text { from the view that the } \\
\text { curriculum harus concerned to } \\
\text { transmit the culture of the } \\
\text { society }\end{array}$ & $\sqrt{ }$ & & \\
\hline 4. & $\begin{array}{l}\text { Its mean pluralism budaya } \\
\text { adalah kebanyakan modern } \\
\text { people bersifat pluralism }\end{array}$ & $\sqrt{ }$ & & \\
\hline 5. & $\begin{array}{l}\text { di dalamnya banyak budaya } \\
\text { atau subculture yang berbeda }\end{array}$ & $\sqrt{ }$ & & \\
\hline
\end{tabular}

terkadang tidak sesuai

\begin{tabular}{ll}
\hline keputusan untuk \\
mempertimbangkan culture \\
masyarakat ketika mencoba \\
untuk menyatakan secara \\
spesifik
\end{tabular}

Table 4. Types of Code Mixing Used by Respondent 4 (YYU)

\begin{tabular}{|c|c|c|c|c|}
\hline \multirow{2}{*}{ NO } & \multirow{2}{*}{ Student Utterances } & \multicolumn{3}{|c|}{ Types of code Mixing } \\
\hline & & ICM & ACM & CLCM \\
\hline 1. & $\begin{array}{l}\text { knowledge adalah keakraban } \\
\text { kesadaran atau pemahaman } \\
\text { seseorang terhadap sesuatu }\end{array}$ & $\sqrt{ }$ & & \\
\hline 2. & $\begin{array}{l}\text { Jadi ini merupakan definisi } \\
\text { dari knowledge sendiri yang } \\
\text { dimana segala sesuatu yang di } \\
\text { jelaskan tersebut ialah } \\
\text { merupakan bagian dari } \\
\text { pengetahuan }\end{array}$ & $\sqrt{ }$ & & \\
\hline 3. & $\begin{array}{l}\text { curriculum merupakan suatu } \\
\text { cara atau strategies yang } \\
\text { dapat di capai dalam } \\
\text { memproleh tujuan dari } \\
\text { pembelajaran. }\end{array}$ & $\sqrt{ }$ & & \\
\hline 4. & $\begin{array}{l}\text { Kemudian maksud dari } \\
\text { second point ini yaitu }\end{array}$ & $\sqrt{ }$ & & \\
\hline 5. & $\begin{array}{l}\text { yang di pelajari sifat } \\
\text { problematic dari } \\
\text { pengetahuan manusia dan } \\
\text { fakta yang di hasilkan }\end{array}$ & $\sqrt{ }$ & & \\
\hline
\end{tabular}

Based on the whole excerpts above, there were only two types of code-mixing used by the students. The first was insertion code-mixing and the second was alternation code mixing. From all the code-mixings produced by the students, insertion code-mixing has the bigger portion than alternation code-mixing used by the students. The number was 32 utterances of insertion code-mixing and 9 utterances of alternation code-mixing. The writers did not find the used of congruent lexicalization in the students' presentation process. The frequency of the use of code-mixing is displayed below:

Table 5. the frequency of using code mixing.

\begin{tabular}{ccccc}
\hline \multirow{2}{*}{ No } & Participant & \multicolumn{3}{c}{ Type of code-mixing } \\
\cline { 3 - 5 } & Insertion & $\begin{array}{c}\text { Alternat } \\
\text { ion }\end{array}$ & $\begin{array}{c}\text { Congruent } \\
\text { lexicalization }\end{array}$ \\
\hline 1 & WDM & 10 & 2 & - \\
\hline 2 & SPI & 12 & 5 & - \\
\hline 3 & ASM & 5 & 2 & - \\
\hline 4 & YYU & 5 & - & - \\
\hline \multicolumn{2}{r}{ Total Amount } & $\mathbf{3 2}$ & $\mathbf{9}$ & $\mathbf{0}$ \\
\hline
\end{tabular}

After analyzing and classifying the data, the researchers found there were only two reasons why did the students mixed their utterances, those are; the vocabulary and situation factor. 
The researchers concluded the result by using Nababan"s theory.

a. Vocabulary

The first reason why did the students used code-mixing? the researchers got the reason from the participants (SPI, YYU). The reason was at the moments the participants had a lack of vocabulary or difficulties to find out the appropriate word in English, thus they applied Indonesian words into their English utterances. It can be seen from the following example:

\section{Excerpt 1.}

"I use code mixing because sometime when I talk to other people or during a presentation in the class, I often forget and do not even know the vocabulary of the English words that I will use, so I mix them with Indonesia".

The excerpt 1 is the personal answer of SPI about the reason of code-mixing usage. SPI used Indonesian-English code-mixing to present the material in the classroom. Despite all, that he applied the Indonesian word into English utterances. It means, the students used code-mixing because they had lacked of vocabulary when speak in English. And based on the Nababan"s theory, this reason included into "lack of vocabulary" factor.

\section{b. Situation}

The students (ASM, WDM) often use Indonesian-English code-mixing for a specific purpose. The participants used code-mixing to clarify what did they mean in the different languages or to make it easier for the interlocutor in understanding what did the speakers meant.

\section{Excerpt 2.}

"I used code mixing because in my class there are several lecturers who requires it to use English, and some who do not require it, while my skills are not yet maximal so I apply the Indonesian words into English utterances when explaining the material".

The excerpt 2 is the personal reason of ASM about the reason of code-mixing usage. ASM used Indonesian-English code-mixing to present his material in the classroom, and there were several lecturers who required to use English. Based on the reason above, it can be concluded that the reason of students used code-mixing because of the situation.
Table 6. the factors that influence the students in using code mixing

\begin{tabular}{llcccc}
\hline NO & Partic & \multicolumn{3}{c}{ The Factors } \\
\cline { 3 - 6 } & ipants & $\begin{array}{c}\text { Bilingua } \\
\text { lism }\end{array}$ & $\begin{array}{c}\text { Vocabul } \\
\text { ary }\end{array}$ & Situation & Prestige \\
\hline 1. & SPI & & $\sqrt{ }$ & \\
\hline 2. & YYU & & $\sqrt{ }$ & \\
\hline 3. & ASM & & $\sqrt{ }$ \\
\hline 4. & WDM & & $\sqrt{ }$ \\
\hline
\end{tabular}

\section{CONCLUSIONS AND SUGGESTIONS}

\section{A. Conclusions}

Overall in can be conclude that there were two types of code-mixing found in the students' utterances during presentation process in the classroom. They are insertion code-mixing, and alternation code-mixing and the results showed that the most frequently used was insertion code-mixing which was occured in a formal situation. And in this research, the researchers just observed at the formal situation, in the teaching and learning process. From the interview with the students, the researchers found two reasons why did the students used code-mixing in the teaching learning process, the reasons of the students used code-mixing in the presentation process during classroom activity were situation and lack of vocabulary factors.

\section{B. Suggestions}

The researchers expected that the students should frequently use code-mixing at any presentations in the classroom to improve their confidence in using English. Whereas, the teachers should minimize in using codemixing in the classroom. Then the writers also suggest to the next researchers to conduct similar study with more complete data and discussion. It is expected that the result of this study is going to lead the next researchers who will conduct the same topic of research as one of the references or it can be a comparison that might be relevant to their research discussion. Finally, the writers hope this research can give a pisitive contribution to people and readers especially to the English language learners.

\section{REFERENCES}

Hamsia, W. (2015). Code Mixing and Code Switching in Umar Kayam"s Novel Parapriayi. 15(1), 36.

Handayani, S. (2016). Pentingnya berbahasa inggris dalam menyongsong asean. Jurnal Profesi Pendidik. 3(1), 102-106. 
Ho, J. W. Y. (2007). Code-mixing: Linguistic form and socio-cultural meaning. The International Journal of Language Society and Culture, 21, 1-8.

Ivana, D. (2018) "An Analysis of Code Mixing Used by English Teachers in Teaching Learning Process at Mas Pab 2 Helvetia". Thesis. English Education Department. Islamic University of North Sumatera. Medan.

Khairunnisa. (2016). "Code Mixing Analysis in English Teaching Learning Process at Senior High School 1 Takalar". Thesis. English Education Department Tarbiyah And Teaching Science. Alauddin State Islamic University. Makassar.

Marlina, L. (2016). Bilingualism and bilingual experiences: A Case of Two Southeast Asian female student at deakin university. UNP Journals, 10(2), 182-193.

Martinez, M. R. P. (2011). CLIL and cooperative learning. Encuentro. 109-118.
Moleong, L.J. (2013) Metode Penelitian Kualitatif. Bandung: PT Remaja Rosdakarya.

Muflihah, (2016). "Code switching and code mixing dalam komunikasi di lingkungan IAIN Purwokerto (suatu kajian sosiolinguistik)", KOMUNICKA, 10(1), 94107.

Muysken, P. (2000). Bilingual Speech: A Typology of Code Mixing. Cambridge: Cambridge

Sukrisna, A. (2019). "An Analysis of using Code Mixing on Atta Halilintar's Video Youtube Channel". Thesis. Tarbiyah and Teacher Training Faculty. Raden Intan State Islamic University. Lampung.

Wardhaugh, R. (2016). An Introduction to Liguistic. Australia: Blackwell Publishing Ltd. 